\title{
Effect of Multimedia Instructional Strategy on Students' Academic Achievement in Mechanical Trades in Technical Colleges
}

\author{
T. I. Eze ${ }^{1}$, B. O. Olumoko ${ }^{2} \&$ M. N. Obi ${ }^{1}$ \\ ${ }^{1}$ Department of Technology \& Vocational Education, Nnamdi Azikiwe University, Awka, Nigeria \\ ${ }^{2}$ Department of Vocational and Technical Education, Adekunle Ajasin University, Akungba-Akoko, Ondo State, \\ Nigeria \\ Correspondence: T. I. Eze, Department of Technology \& Vocational Education, Nnamdi Azikiwe University, \\ Awka, Nigeria. E-mail: tylodubaeze@yahoo.com.
}

Received: April 6, 2020

doi:10.20849/jed.v4i2.757
Accepted: June 5, 2020

Online Published: June 19, 2020

URL: https://doi.org/10.20849/jed.v4i2.757

\begin{abstract}
The need to improve academic performance of technical college students in mechanical trades necessitated this study. Thus the study proceeded to determine the effect of teaching mechanical trades concepts with multimedia on students' academic achievement in technical colleges. One research question guided the study and one null hypothesis was tested at 0.05 alpha level. The study employed a pretest, posttest, quasi-experimental design involving two non-equivalent intact groups, (experimental group and the control group). The population was 123 National Technical College II (NTC II) students offering mechanical trades in Ondo State Nigeria. A sample of 84 students participated in the study. Purposive sampling technique was used to select two intact classes in Government technical colleges from two different local government areas of the State. Three data collection instruments, namely, the lesson plan for the experimental group, the lesson plan for the control group and the Mechanical Trade Achievement Test (MTAT) were used for the study. These were validated by three experts (one from Measurement and Evaluation unit and two from Technology and Vocational Education) all from Nnamdi Azikiwe University, Awka. The MTAT was subjected to a reliability test using Kuder Richardson 21 (KR-21) formula to yield the reliability coefficient of 0.82 . Mean as well as Analysis of Covariance (ANCOVA) were used to analyze at 0.05 level of significance the data collected for the study. Findings of the study revealed that teaching with multimedia was more effective in enhancing student's achievement in mechanical trade. Based on the findings, it was concluded that multimedia technology is more effective in improving student's achievement in mechanical trade. Consequently it was recommended that technical college mechanical trade teachers should adopt teaching with multimedia.
\end{abstract}

Keywords: multimedia, academic achievement, mechanical trades, technical college

\section{Introduction}

Multimedia technology is being increasingly integrated into teaching and learning process for the purpose of meeting the teaching and learning challenges facing the educational system. Indeed, the introduction of multimedia technology into the classroom has profound impact on the styles of teaching and learning thus making the students to be more motivated to learn (Cyril, 2016) and being able to create their own knowledge (Ogundola, Popoola \& Jonathan, 2010), as well as being able to work at different paces to satisfy their own needs (Slack, 1999). Many researchers (for example, Junaidu (2008), who have worked on multimedia have seen multimedia as those ICT based learning technologies that encompass different contents as texts, audio, images, animations, motion video, sounds, graphic images among others. Thus it is often applied as an instructional strategy.

Interestingly, multimedia is an exciting combination of computer hardware and software that allows the learner and teacher to integrate video, animation, audio, graphics and text resources to develop effective presentations in an affordable desktop computer (Udofia, Ekpo, Nsa \&Akpan, 2012). The authors went on further to state that multimedia technology goes beyond barriers of time, location and culture and has created many better opportunities for learning outside the classroom using online materials. The same multimedia software content can also be packaged and delivered over satellite and broadband technologies for distance learning. Here, the students learn the materials at their own time and interact with the teacher via video-conferencing as it was found 
in their curriculum (Adegoke, 2010). The average school-age child spends much time watching television, playing video games and exploring other electronic media devices, including the cell phones. These are methods that deploy multimedia.

Multimedia technology is therefore used for the upliftment of modern teaching styles since it satisfies, consistent with UNESCO \& ILO (2003), both the visual and auditory senses of students, thus helping the students to get involved in the learning process as they actually participate in the learning while constructing their own knowledge. Furthermore, according to Patel (2013), multimedia has been effectively tested and widely accepted to enhance skill achievement in English language teaching. Patel further contended that English language being the language of social context, political, socio-cultural business, education and industry, whatever enhances skill in the subject could also enhance skill in other subjects. But this assertion needs to be empirically tested and sustained, as it concerns academic achievement in vocational technical subjects like the mechanical trades.

Udofia, Ekpo, Nsa and Akpan, (2012) and Cyril (2016), have stressed that inadequate instructional techniques do not enhance students' acquisition of skills and development of self-concept as well as interest. It may rather make it difficult for the students to develop the right habit for job performance which is often dependent on teaching method(s). These explorations and manipulations are great developments in education which have further stimulated interest and created enabling environments for learning to take place both inside and outside the classrooms especially for technical college students. Correspondingly, the extent of learning is measured by academic achievement.

Academic achievement reflects the extent to which the student has accomplished set tasks or goals in an educational instruction. (Eze, Obidile \& Okotobu, 2020). It is indeed the result of the successful interaction between the students and their teachers (Igbo \&Ihieme, 2014).

According to Eze, Ezenwafor and Muolokwu (2015) academic achievement is a measure for estimating the students' success in an educational endeavour or in meeting the standard set by examining bodies. Specifically academic achievement determines the individual's level of skill accomplishment or knowledge (cognitive, affective and psychomotor) in a specific subject area, like mechanical trades.

Mechanical trades are among the subjects offered in Nigeria's vocational technical institutions otherwise called the technical colleges. The thrust of academic and skill work at the technical colleges is to produce the graduates who will ultimately function as crafts-men and technicians who will work in industries. The effectiveness of these craftsmen and technicians in industries will mostly depend on how effectively they are educated and trained. This will depend on the teaching method(s) used.

As (Cyril, 2016) would put it, the traditional face-to-face teaching method (the lecture and demonstration usually teacher centered) often used in instructing the students in the technical colleges often created learning difficulties and could also create frustration and lack of vocational interest for the students. This results in poor students performances in the public examinations as reported in the Chief Examiner's reports of National Business and Technical Examination Board (NABTEB) of 2014, and 2016. The Chief Examiner's Reports went further to fault the teaching method(s) used in the technical colleges. Hence there is the need to search for more modern student centered teaching method, which could enhance students' learning and thus improve academic achievement. Since (Patel, 2013) has asserted that the multimedia enhances skill development in subject areas as seen in English language, and in electronics, data sciences and physics, as held by Bin Yuan, (2017), these researchers have adopted the multimedia instructional strategy to teach general mechanical trades in technical colleges to see if it could as well enhance learning and hence achievement.

\section{Purpose of Study}

The purpose of this study is therefore to determine the effect on the mean achievement scores of technical college mechanical trade students when they are taught with the multimedia instructional strategy and when they are taught with the conventional (lecture/demonstration) instructional strategy. The technical college students in Ondo technical colleges were used for the study.

\section{Research Question}

The following research question guided the study:

What is the effect on the mean achievement scores of mechanical trade students taught with multimedia and those taught with the conventional method?

\section{Hypothesis}

The following null hypothesis was tested at 0.05 level of significance: 
There is no significant difference between the mean achievement scores of mechanical trade students taught with multimedia and those taught with the conventional method.

\section{Method}

The research study adopted a quasi-experimental design which involved the pre-test, post-test for unequal (experimental and control) groups (Nworgu, 2015). This is primarily because the study was to find out the effect on mean achievement scores of the mechanical trade students when they are caught with multimedia instructional strategy and when they are taught with the convectional (demonstrations) instructional strategy.

The population of 123 National Technical College II (NTC II) students offering mechanical trade in Ondo State, Nigeria was targeted for the study. By purposive sampling technique two intact classes, 43 (39 males, and 4 females) from Government Technical College Owo (GTC) and 41 (34 males and 7 females) from Government Technical College (GTC), Idanre, were chosen for the study. These two technical colleges were quite apart from each other. Both schools had facilities for teaching with multimedia and demonstration strategies. By the random sampling (toss of the coin), the GTC Owo was designated the experimental group while the GTC Idanre was designated the control group. Thus a total sample of 84 students participated in the study.

The instrument for data collection were the lesson plan for the experimental group, lesson plan for the control group and the mechanical trade achievement test (MTAT) made up of 50 objective question (test) items developed by the researchers from the National Business and Technical College Examinations (NABTEB) past question papers. The test items in the objective question papers concentrated on the basic mechanical concept of engine maintenance, parts of the engine and engine overall. Lesson plans developed by the researchers for the regular class teachers (trained as research assistant ants) in the schools concentrated on the use of those two strategies (multimedia and demonstration) for teaching the mechanical trade concepts under the study. The students were taught in their normal classroom within the school time.

Both the instrument (MTAT) for data collection and the lesson plans were validated by three experts (two from the mechanical unit of technology to Vocational Education Dept, and one from Measurement and Evaluation unit of Education Foundation Dept.) from Nnamdi Azikiwe University, Awka. To establish the reliability of (MTAT) the test instrument, the researchers administered copies of the instrument (MTAT) to 32 NTC II mechanical trade students from Government Technical College, Benin City, Edo State Nigeria who were not part of the study. Data collected thus were analyzed using Kuder Richardson formula 21 (KR21) which yielded the reliability coefficient of 0.82 .

Using MTAT, both the control and the experimental groups were pre-tested. Thereafter the experimental group was taught the mechanical trade concepts with multimedia instructional strategy while the control group was taught with the conventional (demonstration) instructional strategy for five weeks, by their regular class teachers (research assistants) and in their schools. After teaching (treatment), both the experimental and control groups were exposed to post-test. The contents of the pretest and post-test were the same, except that the contents were reshuffled and the color of the paper changed. The researchers thereafter marked the test and accordingly recorded the scores as the data for the srudy.

The researchers statistically analyzed the data using mean for research question while the standard deviation was used to determine the spread of the scores about the means. The hypothesis was tested using the Analysis of Covariance (ANCOVA) at 0.05 level of significance. The ANCOVA is very effective in controlling the initial differences between the tests groups, particularly when there was no randomization within the groups.

\section{Results}

Research Question: What is the effect on the mean achievement scores of mechanical trade students taught with multimedia and those taught with the conventional method?

In answering the research question, Table 1 was used.

Table 1. Mean and Standard deviations of the experimental and control groups' achievement in pre-test and post-test

\begin{tabular}{llllll}
\hline Method & Pre-test & & Post-test & & Mean difference \\
\hline & Mean & Std & Mean & Std & \\
\hline $\begin{array}{l}\text { Experimental Group } \\
\text { (Multimedia) }\end{array}$ & 16.12 & 4.77 & 31.59 & 3.97 & 15.47 \\
\hline $\begin{array}{l}\text { Control Group } \\
\text { (Conventional) }\end{array}$ & 3.42 & 4.81 & 19.22 & 3.37 & 5.81 \\
\hline
\end{tabular}


The results in Table 1 show that the scores for pretest and posttest is 16.12 and 31.59 respectively with a mean difference of 15.47 for the experimental group while that of the control group is 13.42 and 1922 respectively for the pre-test and post-test with a mean difference of 5.81. This shows that the experimental group has a higher mean difference. The inference from this result shows that the multimedia method has greater effect on the students achievement scores than the conventional method.

Hypothesis: There is no significant difference between the achievement scores of mechanical trade students taught with multimedia and those taught with the conventional method.

The answer to the hypothesis is presented in Table 2

Table 2. ANCOVA summary of achievement scores of mechanical trade students taught with multimedia and conventional method

\begin{tabular}{llllllll}
\hline Source & df & Sum of square & Mean sum squares & F-cal & F-tab & Sig. & Remarks \\
\hline Method (Strategy) & 1 & 1475.694 & 1475.694 & 110.925 & 3.96 & 0.000 & Rejected \\
\hline Gender & 1 & 12.091 & 12.091 & 0.909 & 3.96 & 0.343 & Not rejected \\
\hline Method $\times$ Gender & 1 & 6.061 & 6.061 & 0.456 & 3.96 & 0.502 & Not rejected \\
\hline Error & 80 & 1064.283 & 13.304 & & & & \\
\hline Total & 83 & & & & & & \\
\hline
\end{tabular}

What is being tested here is the significance of the difference between the two teaching strategies (methods). Thus the results in Table 2 show that at 0.05 level of significance with the 1 degree of freedom (df), the p-value of 0.000 is lower than 0.05 level of significance, and that also the F-calculated of 110.925 is greater than F-table of value 3.90. Therefore the null hypothesis is rejected. Thus there is statistical significant difference between the mean when multimedia was used in teaching and the mean when the demonstration method was used in teaching. Hence the multimedia teaching strategy enhanced mechanical student's achievement in technical colleges.

Although gender effect consideration was not the focal point of this study, the gender effect consideration was not significant. Thus it could be said that gender does not necessarily influence the student achievement. Similarly the interaction of gender and the method (teaching strategy) is not significant in this study. This reinforces the earlier assertion. Indeed, this result shows that there is a significant difference between the achievement scores of mechanical trade students taught with multimedia and those taught with the conventional method. Based on this result, the null hypothesis is rejected.

\section{Discussion}

The results from the research questions and the hypothesis all agree that students taught with multimedia instructional strategy have better academic achievement than the students taught with the conventional teaching method (demonstration). It does show that the multimedia teaching strategy enhanced the students' acquisition of skill and knowledge. This is consistent with the assertions of Patel (2013) and Bin Yuan (2017). Thus we can infer that multimedia technology could enhance skill acquisition across subject areas.

Findings from this study further agrees with the assertions of (Agnew 2006) and Omagbemi (2004) that teaching with multimedia stimulates changes and creates conductive learning environment and make learning more meaningful and responsive to the localized specific needs of learners. This portends that teaching with multimedia enhances students learning ability through active learning.

\section{Conclusion}

The study showed that teaching with multimedia enhanced students' academic achievement in mechanical trades. This indicates that teaching with multimedia is an effective method of teaching mechanical trades at NTC level in the sense that it enabled students to learn very well. It is therefore, concluded that, teaching with multimedia could foster mastery of concepts and also could enhance students' academic achievement in mechanical trades.

\section{Recommendations}

Based on the findings and conclusion of the study, the following recommendations are made: 
i. Curriculum planners of technical college programmes should collaborate with mechanical trades' experts to develop workable motor vehicle mechanics work curriculum that will accommodate teachers' use of multimedia for effective instructional delivery.

ii. Mechanical trade teachers should use multimedia in teaching to enable students learn and to improve their academic performance.

iii. Mechanical trade students should be encouraged and motivated to consistently use multimedia in learning. This can make them master the skills so as to be more creative in knowledge application and consequently enhance their academic achievement and retention.

iv. Ministries of Education should synergize with school administrators to create a platform, such as workshop and seminars to impart teachers' requisite competencies effectively using multimedia in teaching.

\section{References}

Adegoke, B. A. (2010). Integrating animations, narrations and textual materials for improving student's learning outcomes in senior secondary school physics. Electronic Journal of Research in Educational Psychology, 2(1), 56-65.

Agnew, R. (2006). Story lines as a neglect cause of crime. Journal of Research in Crime and Delinquency, 43(2), 119-147. https://doi.org/10.1177/0022427805280052

Bin, Y. (2017). AIP Conference Proceeding 1820. https://doi.org/10.1063/14977412

Chief Examiners' Report. (2014). National Business and Technical Examination Board Reports, (NERDC). Nigeria Education and Research Development Council, Nigeria.

Chief Examiners' Report. (2016). National Business and Technical Examination Board Report, (NERDC). Nigeria Education and Research Development Council, Nigeria.

Cyril, M. U. (2016). Effects of Multimedia Instruction on Retention and Achievement of Basic Skills in Mechanical Craft Practice. International Journal of Education and Information Technology, 2(1), 1-7. Retrieved from www.aiscience.org/journal/jet

Eze, T. I., Ezenwafor, J. I., \& Muolokwu, L. I. (2015). Effect of Meta-learning Teaching Method on the Academic Performance of Building Trades Students in Technical Colleges in South-East Nigeria. International Journal of Vocational Technical Education, 7(10), 101-108. Retrieved from www.academicjournals.org/IJVTE

Eze, T. I., Obidile, J. I., \& Okotubo, O. O. (2020). Effect of Gender on Students Academic Achievement and Retention in Auto Mechanics Technology in Technical Colleges in Delta State Nigeria. London Journal of Research in Humanities and Social Sciences, 20(1), 25-32. https://doi.org/10.5430/irhe.v5n1p34

Federal Republic of Nigeria. (2013). National Policy on Education. Lagos: Education Research and Development Council Press.

Igbo, J. N., \& Ihejieme, M .A. (2014). Gender Differences, Delinquent Behaviours and Academic Achievement of Secondary School Students in Nigeria. International Journal of Latest Research in Science and Technology, (4), 2278-5299.

Nwanekezie, A. U., \& Kalu, N. E. (2012). Effect of Multimedia on Primary School Pupils Retention and Interest in Basic Science Concepts. An International Multidisciplinary Journal Ethiopia, 6(2), 206-214. https://doi.org/10.4314/afrrev.v6i2.18

Nworgu, B. G. (2015). Educational research: basic issues and methodology. Ibadan, Wisdom Publishers.

Ogundola, I. P., Popoola, A., \& Jonathan, O. O. (2010). Effect of Constructivism Instructional Approach on Teaching Practical Skills to Mechanical Related Trade Students in Western Nigeria Technical Colleges. International NGO Journal, 5(3), 59-64.

Patel, C. (2013). Use of Multimedia Technology in Teaching and Learning Skill: An Analysis. International Journal of Advancements in Research and Technology, 2(7), 116-123.

Sahalu, J. (2008). The Effectiveness of Multimedia in Learning \& Teaching Data Structures online. Turkish Online Journal of Distance Education, 9(4), 97-106.

Slack, R. (1999). PEDACTICE - The use of Multimedia in Schools.Center for Educational Sociology, St. John's Land, Hollywood Road Edinburgh, U.K. 
Udofia, A. E., Ekpo, A. B., Nsa, E. O., \& Akpan, E.O. (2012). Instructional Variables and Students' Acquisition of Employable Skills in Vocational Education in Nigerian Technical Colleges. Scholarly Journal of Education, 1(2), 13-19. Retrieved from http://www.scholarly-journals.com/SJE33

United Nations Education, Scientific \& Cultural Organization (UNESCO) and International Labour Organization (ILO). (2002). Technical and Vocational Education System in the $21^{\text {st }}$ Century. Retrieved from http://www.unscodoo.org

\section{Copyrights}

Copyrightforthisarticleisretainedbytheauthor(s),withfirstpublicationrightsgrantedtothejournal.

Thisisanopen-accessarticledistributedunderthetermsandconditionsoftheCreativeCommonsAttributionlicense(http: //creativecommons.org/licenses/by/4.0/). 